University of Wollongong

Research Online

Faculty of Engineering - Papers (Archive)

Faculty of Engineering and Information

Sciences

$1-1-2011$

\title{
Physical and chemical ground improvement for sustainable transportation infrastructure under cyclic loads
}

Buddhima Indraratna

University of Wollongong, indra@uow.edu.au

Cholachat Rujikiatkamjorn

University of Wollongong, cholacha@uow.edu.au

Jayan S. Vinod

University of Wollongong, vinod@uow.edu.au

Sanjay Nimbalkar

University of Wollongong, sanjayn@uow.edu.au

Follow this and additional works at: https://ro.uow.edu.au/engpapers

Part of the Engineering Commons

https://ro.uow.edu.au/engpapers/914

\section{Recommended Citation}

Indraratna, Buddhima; Rujikiatkamjorn, Cholachat; Vinod, Jayan S.; and Nimbalkar, Sanjay: Physical and chemical ground improvement for sustainable transportation infrastructure under cyclic loads 2011, 140-156.

https://ro.uow.edu.au/engpapers/914

Research Online is the open access institutional repository for the University of Wollongong. For further information contact the UOW Library: research-pubs@uow.edu.au 


\title{
PHYSICAL AND CHEMICAL GROUND IMPROVEMENT FOR SUSTAINABLE TRANSPORTATION INFRASTRUCTURE UNDER CYCLIC LOADS
}

\author{
B. Indraratna, C. Rujikiatkamjorn, J. S. Vinod, and S. Nimbalkar \\ Centre for Geomechanics and Railway Engineering, \\ School of Civil, Mining and Environmental Engineering, University of Wollongong, \\ Wollongong City, NSW 2522, Australia
}

\begin{abstract}
Railways form one of the major worldwide transportation networks and they continue to provide quick and safe public and freight transportation. In order to compete with other modes of transportation and to meet the ever growing demand of public and freight transport, railway industries face challenges to improve their efficiency and decrease the costs of maintenance and infrastructure. Large cyclic loading from heavy haul and passenger trains often leads to progressive deterioration of the track. The excessive deformations and degradations of the ballast layer and unacceptable differential settlement or pumping of underlying soft and compressible subgrade soils necessitate frequent costly track maintenance works. Hundreds of millions of dollars are spent each year for the construction and maintenance of rail tracks in large countries like the USA, Canada and Australia. A proper understanding of load transfer mechanisms and their effects on track deformations are essential prerequisites for designing the new track and rehabilitating the existing one. The reinforcement of the track by means of geosynthetics leads to significant reduction in the downward propagation of stresses and assures more resilient long-term performance. The geocomposite (combination of biaxial geogrid and non-woven polypropylene geotextile) serves the functions of reinforcement, filtration and separation, thereby reducing the vertical and lateral deformations.

To stabilise subgrade soil under rail tacks and road embankments, two advanced ground improvement schemes have been introduced. Stabilization of soft subgrade soils using prefabricated vertical drains (PVDs) is essential for improving overall stability of track and reducing the differential settlement during the train operation. The effectiveness of using geocomposite geosynthetic and PVDs has been observed through field measurements and elasto-plastic finite element analyses. These have been the first fully instrumented, comprehensive field trials carried out in Australian Railways, and it was very encouraging to see the field observations matching the numerical predictions. Moreover, the improvement of an unstable formation soil with $\mathrm{pH}$ neutral chemical admixture and the sub-surface drainage is described. Internal erosional behaviour of lignosulfonate treated erodible soils has been studied using the Process Simulation Apparatus for Internal Crack Erosion (PSAICE) designed and built at the University of Wollongong (UOW). Effectiveness of lignosulfonate treated erodible soils on the erosion resistance has been investigated and its advantages over conventional methods are presented and discussed.
\end{abstract}

Keywords: Chemical stabilization, Cyclic load, Geosynthetics, Ground improvement, Rail track, Vertical drains

\section{INTRODUCTION}

Railways form the largest worldwide network catering for public and freight transportation. Improving railway efficiency and reducing maintenance and infrastructure costs are major challenges faced by railway industries. Railway tracks are deformed by the degradation of ballast particles. The degradation of ballast is influenced by several factors including the amplitude, frequency and number of load cycles, gradation of aggregates, track confining pressure, and the angularity and fracture strength of individual grains. Several researchers has highlighted ballast breakage and confining pressure as key parameters in the design of ballasted rail tracks (Marshal 1973, Indraratna et al. 1998, 
2004, 2005, Indraratna and Salim 2002, Salim and Indraratna 2004, Lackenby et al. 2007). The cost of track maintenance can be significantly reduced if the geotechnical behaviour of the ballast layer is properly assessed. The potential use of geosynthetics to improve track stability and reduce the maintenance cost is well established (Selig and Waters 1994, Indraratna and Salim 2003). The reinforcement of the track by means of geogrids provides additional confinement to the ballast layer, which leads to significant reduction in the downward propagation of stresses and plastic deformations, and assures more resilient long-term performance of the ballast layer (Rowe and Jones 2000, Raymond 2002, Indraratna and Salim 2005, Indraratna et al. 2003, 2007, ). The geocomposite layer serves the functions of reinforcement, filtration and separation, thereby effectively reducing the vertical and lateral deformations of ballasted track.

Many coastal regions of Australia contain very soft clays, which have undesirable geotechnical properties such as, low bearing capacity, high compressibility and low permeability. In the absence of appropriate ground improvement, the soft deposits with high volumes of plastic clays can generate high excess pore water pressures during both static and cyclic (repeated) loading. The combination of preloading with prefabricated vertical drains (PVDs) is widely considered to be a low cost solution of improving the performance of thick deposits of soft clays. When PVDs are installed in the ground, the drainage path (radial flow) is shortened, thereby reducing the consolidation time. In this paper, a case study of using short PVDs beneath a rail track on soft formation is presented. The background of the project and the soil improvement technique adopted including field instrumentation are described. Design methodology and finite element analysis are reported and discussed through associated settlement and lateral displacement.

Apart from subsurface drainage, chemical stabilization is another effective ground improvement technique to stabilise soft and unstable grounds. The admixtures (stabilizing agents) such as cement, lime, fly ash, gypsum etc generally alter the mineralogical structure of the clay and improve the inherent properties of the soil such as strength and stiffness. Vast numbers of studies were conducted to investigate the applicability of traditional stabilisers on problematic soils such as soft clay and erodible soils (e.g. Uddin et al. 1997; Balasubramaniam et al. 1998; Indraratna et al. 1995; Rajasekaran et al. 1997, Chew et al. 2004).

Apart from providing subsurface drainage, chemical stabilization is an effective ground improvement technique for controlling stabilizing soft and unstable grounds. The admixtures (stabilizing agents) such as cement, lime, fly ash, gypsum etc generally alter the mineralogical structure of the clay and improve the inherent properties of the soil such as strength and stiffness. Vast numbers of studies were conducted to investigate the applicability of traditional stabilisers on problematic soils such as soft clay and erodible soils (e.g. Uddin et al., 1997; Balasubramaniam et al., 1998; Indraratna et al., 1995; Rajasekaran et al., 1997; Chew et al., 2004).

The conventional cemented soils (often alkaline due to cement, lime and gypsum treatment) have shown brittle behaviour (e.g. Sariosseiri and Muhunthan (2009)) especially under cyclic loads, affecting the stability of high speed rail embankments and aircraft runways. Moreover, the conventional cemented soils (often alkaline due to cement, lime and gypsum treatment) have shown brittle behaviour (e.g. Sariosseiri and Muhunthan, 2009) especially under cyclic loads, which affect the stability of high speed rail embankments and aircraft runways. Furthermore, the decrease of porosity and permeability can also occur due to conventional chemical treatment that contributed to drainage reduction(e.g. Rajasekaran and Narasimha Rao, 1997; and Desmet et al. 1985). To overcome these difficulties, researchers are now looking for alternative soil stabilisers for maintaining sufficient ductile soil properties, thereby preventing brittle (tensile) cracking. In the above context, lignosulfonate has shown a promising prospect as a stabilizing agent especially for numerous erodible and dispersive soils in Australia. Preliminary investigation showed that, amount of lignosulfonate required to stabilize soft/unstable soils is much less comparing to other admixtures such as cement, lime, or fly ash. Furthermore, it has also been observed that stress strain and volume change behaviour is distinctly different from those stabilised with traditional admixtures and that the lignosulfonate soils maintain the ductile characteristics. Only a few studies are reported in the literature, hence, the mechanism of soft soil stabilization by lignosulfonate is not well understood. 


\section{USE OF GEOCOMPOSITE UNDER RAILWAY TRACK}

In order to investigate train traffic induced stresses and track deformations, as well as benefits of using geosynthetics in fresh and recycled ballast, a field trial was carried out on a real instrumented track (Indraratna et al. 2010). The University of Wollongong provided technical specifications for the design, while RailCorp, Australia provided funding to build a section of highly sophisticated instrumented track at Bulli along the New South Coast.

\section{Track Construction}

The proposed site for track construction was located between two turnouts at Bulli along the New South Coast. The total length of the instrumented track was $60 \mathrm{~m}$, which was divided into four sections, each of $15 \mathrm{~m}$ length. The depths of load bearing ballast and capping layer were $300 \mathrm{~mm}$ and $150 \mathrm{~mm}$, respectively. Concrete sleepers were used. The detailed layout of four sections is shown below (Figure 1). Fresh and recycled ballast without geocomposite layer were used at two sections (Section $1 \& 4$ ), while other two sections were built by placing a geocomposite layer at the base of the fresh and recycled ballast, respectively (Figure 2).

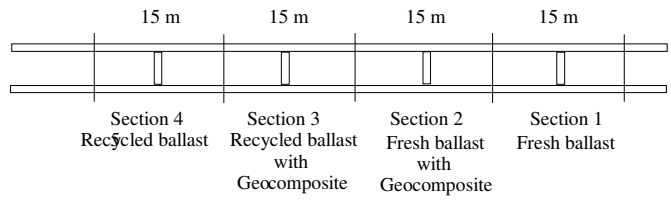

Figure 1: Layout of the instrumented track at Bulli.

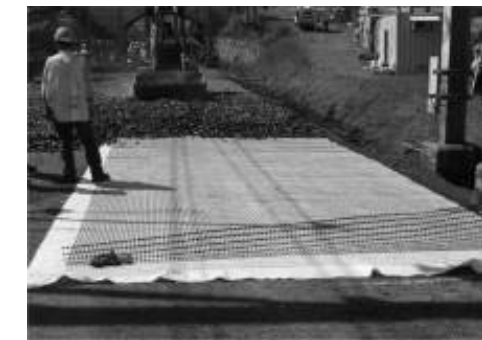

Figure 2: Installation of geocomposite under the ballast at Bulli.

\section{Material Specifications}

The particle size, gradation and other index properties of fresh ballast used at the Bulli site were in accordance with the Technical Specification TS 3402 (Railcorp, Sydney), which represents sharp angular coarse aggregates of crushed latite basalt. Recycled ballast was collected from spoil stockpiles of a recycled plant commissioned by RailCorp at their Chullora yard near Sydney. The capping material was comprised of a sand-gravel mixture. The particle size distribution of fresh ballast, recycled ballast and the capping (sub-ballast) materials are shown in Fig. 3. Table 1 shows the grain size characteristics of these materials (Indraratna and Salim, 2005; Ionescu, 2004).

Table 1: Grain size characteristics of ballast and capping materials (Indraratna et al., 2010).

\begin{tabular}{|l|c|c|c|c|c|c|}
\hline Material & Particle shape & $\begin{array}{c}d_{\max } \\
(\mathrm{mm})\end{array}$ & $\begin{array}{c}d_{\min } \\
(\mathrm{mm})\end{array}$ & $\begin{array}{c}d_{50} \\
(\mathrm{~mm})\end{array}$ & $C_{u}$ & $C_{c}$ \\
\hline Fresh Ballast & Highly angular & 75.0 & 19.0 & 35.0 & 1.5 & 1.0 \\
\hline Recycled Ballast & Semi-angular & 75.0 & 9.5 & 38.0 & 1.8 & 1.0 \\
\hline Capping & Angular to rounded & 19.0 & 0.05 & 0.26 & 5.0 & 1.2 \\
\hline
\end{tabular}

A bi-axial geogrid was placed over the non-woven polypropylene geotextile to serve as the geocomposite layer, which was installed at the ballast-capping interface. The technical specifications of geosynthetic material used at the site can be found in Indraratna and Salim (2005).

\section{Track Instrumentation}

The performance of each section under the cyclic load of moving trains was observed by using sophisticated instruments. The vertical and horizontal stresses developed in the track bed under repeated wheel loads were measured by pressure cells. Track vertical deformations at different sections were measured by settlement pegs and lateral deformations were measured by electronic displacement transducers connected to a computer controlled data acquisition system. The settlement 
pegs and displacement transducers were installed beneath the rail and at the end of the sleeper at sleeper-ballast and ballast-capping interfaces, respectively, as shown in Fig. 4.

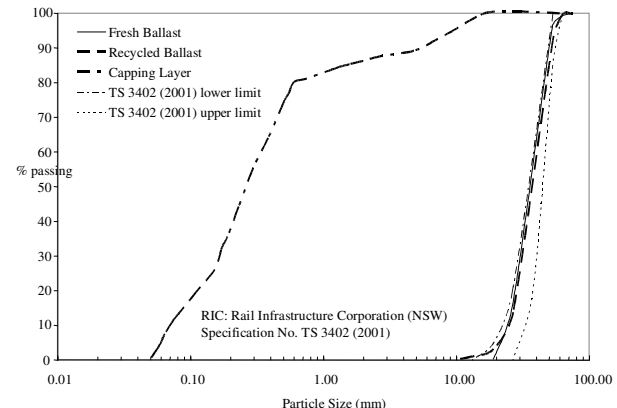

Figure 3: Particle size distribution of ballast and capping materials (Indraratna et al., 2010).

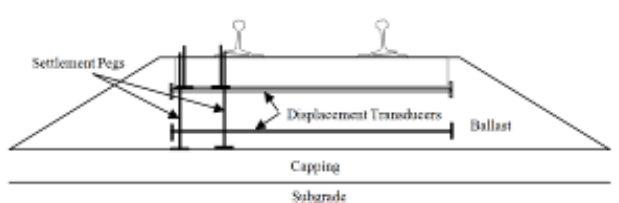

Figure 4: Installing vertical settlement pegs and displacement transducers (Indraratna et al., 2010).

\section{Track Measurements}

\section{Vertical deformations}

In order to investigate the overall performance of the ballast layer, the average vertical deformation was considered by the difference between the vertical displacements of sleeper-ballast and ballastcapping interfaces. The vertical displacement at each interface was obtained by taking the mean of measurements taken under the rail and the edge of sleeper. The vertical and horizontal deformations were measured against time in the field. In order to establish a suitable correlation with other research methodologies, a scale of 'number of load cycles' is selected in addition to the 'time' scale. The values of average vertical ballast deformation are plotted against the number of load cycles $(\mathrm{N})$ in Figure 5. In the recycled ballast, they are smaller comparing to the case of fresh ballast because of its moderatelygraded particle size distribution comparing to the very uniform fresh ballast. The better performance of selected recycled ballast can benefit from less breakage as they are often less angular, thereby preventing corner breakage due to high contact stresses. It is also shown in Figure 5 that the geocomposite inclusion induces decrease in average vertical deformations of both recycled and fresh ballast at a large number of cycles. This is because the load distribution capacity of ballast layer is improved by the placement of a flexible and resilient geocomposite layer which results in a substantial reduction of settlement under high cyclic loading. This particular recycled ballast performed very well, that is, showed less vertical deformations because it was more well-graded than the fresh ballast. If placed as a well graded mix the corners may not break so frequently because their angularity is less.

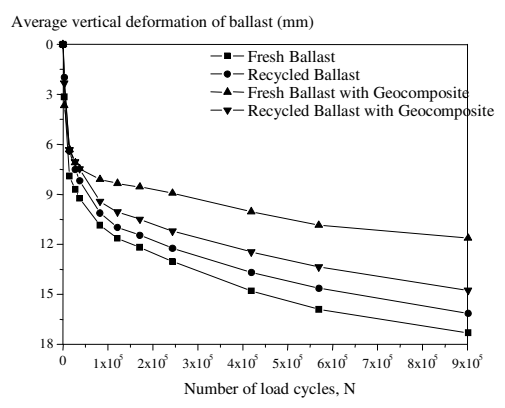

Figure 5: Average vertical deformation of the ballast layer (modified after Indraratna et al., 2010).

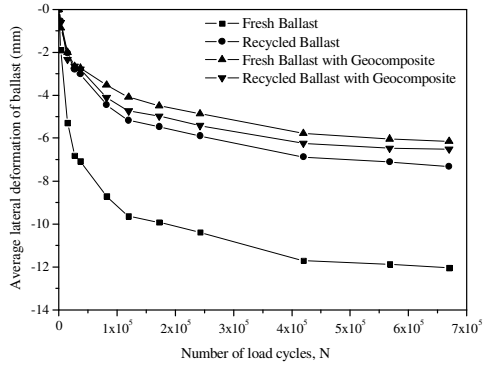

Figure 6: Average lateral deformation of the ballast layer (modified after Indraratna et al., 2010). 


\section{Lateral Deformations}

Figure 6 shows the average lateral deformation of ballast plotted against the number of load cycles (N). Data from the displacement transducers was collected from the data logger at regular time intervals. The average deformations were determined from the mean of measurements at sleeperballast and ballast-capping interfaces. The ballast layer exhibits an increase in the average lateral deformation with $\mathrm{N}$ (i.e. lateral spread, represented by negative sign) in all sections. As shown in Figure 6, the layer of geogrid also reduced the lateral deformation of both fresh and recycled ballast significantly. The track deterioration is a result of accumulated plastic settlements in the track layers and has serious consequences on the passenger comfort, safety and efficiency (speed restriction) during train operation. The effectiveness of geosynthetics in preventing track deterioration is appealing to railway industry, due to the low cost of geosynthetics in relation to substantial savings generated by the extended track life-cycle and more resilient ballast behaviour.

\section{Maximum Stresses in Ballast}

Figure 7 shows the maximum stress induced in the ballast by an 82 class locomotive moving at about $60 \mathrm{~km} / \mathrm{h}$. The maximum vertical stress under the rail reduced by $73 \%$ and $20 \%$ at the base of the ballast layer and capping layer, respectively. Whereas the maximum vertical stress at end of sleepers showed a reduction of $64 \%$ and $45 \%$ at the base of ballast layer and capping layer, respectively. However, the horizontal stress decreased marginally with depth, as is evident from Figure 7. Figure 8 shows the maximum stress recorded in the ballast due to a coal train with 100T wagons. It confirms that the same trend for vertical and horizontal stress recorded under the rail and at end of the sleepers. The observations made in the instrumented section of track at Bulli validate the analytical, numerical, and laboratory investigations carried out at the University of Wollongong and highlight the successful inclusion of geogrid reinforcement in the rail track structures to significantly reduce the deformation and degradation of ballast. A longer maintenance cycle is possible with the use of geosynthetics in the rail track which in turn help defray the high costs associated with maintaining ballasted tracks.
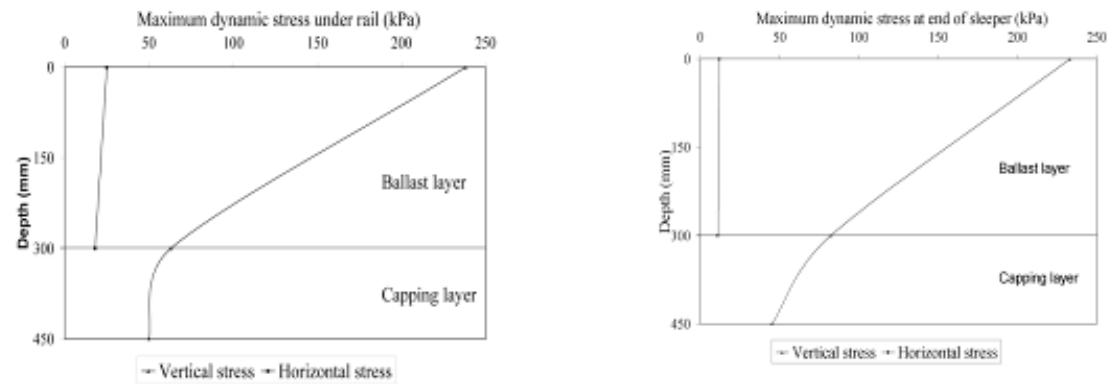

Figure 7: Maximum dynamic pressure measured (a) under the rail (b) at end of the sleepers for an 82 class locomotive.

\section{USE OF GEOSYNTHETIC VERTICAL DRAINS AS A SUBSURFACE DRAINAGE}

Low-lying areas having large volumes of plastic clays can sustain high excess pore water pressures during both static and cyclic (repeated) loading. In poorly drained situations, the increase in excess pore pressures will decrease the effective load bearing capacity of the formation soil. Under certain circumstances, slurrying of clay beneath rail tracks may initiate pumping of the soil upwards, thereby clogging the ballast bed and promoting undrained shear failure (Chang, 1982; Indraratna et al., 1992). Geosynthetic PVDs can be installed to dissipate excess pore pressures by radial consolidation before they can build up to critical levels. These PVDs continue to dissipate excess pore water pressures even after the cyclic load stops (Indraratna et al., 2009). 


\section{Apparatus and Test Procedure}

A series of laboratory tests were carried out using the large-scale cylindrical triaxial equipment. The equipment was further modified to measure the excess pore water pressure at different locations inside the specimen. Miniature pore pressure transducers were fitted through the base of the triaxial rig and then inserted through the specimen pedestal and positioned at the locations shown in Figure 9.

The clay used in this study was kaolinite of specific gravity $G_{s} 2.7$. The liquid limit $w_{L}$ was $55 \%$ and the plastic limit $w_{P}$ was $27 \%$. The compression index $c_{c}$ was 0.42 and the swelling index $c_{s}$ was 0.06. The soil specimens (with and without PVD) were subjected to anisotropic consolidation under an effective vertical stress of $40 \mathrm{kPa}\left(\mathrm{K}_{0}=0.60\right.$ representing the in-situ stress), where $\mathrm{K}_{0}$ is the ratio of the effective horizontal to the effective vertical stress. Double drainage via the top and bottom of the specimen (in addition to radial drainage for tests with PVD) was permitted during the anisotropic consolidation to attain a degree of consolidation of 95\%, (approximately 5 weeks with PVD and 9 weeks without PVD).

Three separate series of tests were conducted: (a) cyclic partially drained with PVD, (b) cyclic consolidated undrained (cyclic $\mathrm{CK}_{0} \mathrm{U}$ ) without PVD and (c) cyclic unconsolidated undrained (cyclic UU) without PVD. A series of conventional monotonic triaxial tests was conducted first according to ASTM (2002) to obtain the maximum deviator stress at failure $\left(q_{f}\right)$ under static loading. Then a cyclic stress ratio (CSR) of 0.65 was selected, where CSR is defined as the ratio of the cyclic deviator stress $q_{c y c}$ to the static deviator stress at failure $q_{f}$. Failure denotes a condition of rapidly accumulating nonrecoverable (permanent) deformations with increasing number of cycles, and this can be represented in a semi-logarithmic plot at the point where the deformation curve starts to concave downwards indicating rapid increase in displacement. It is reported by several researchers that this critical cyclic stress ratio is between 0.6 and 0.7 (Ansal and Erken 1989; Miller et al. 2000; Zhou and Gong 2001). A sinusoidal cyclic load was applied to the specimen under one-way stress-controlled conditions at a frequency of $5 \mathrm{~Hz}$ simulating a $100 \mathrm{~km} / \mathrm{hr}$ train speed. The applied cyclic amplitude was $25 \mathrm{kPa}$. The cyclic load application with PVD was carried out under radial and top drainage with no bottom drainage, in order to simulate the field boundary condition. The tests without PVD were carried out under totally undrained conditions. Membrane corrections were applied according to ASTM (2002). The axial and volumetric deformations were measured using linear variable differential transformers (LVDTs). Also, the measurements of excess pore pressures for all test series were made at the locations shown in Figure 9.
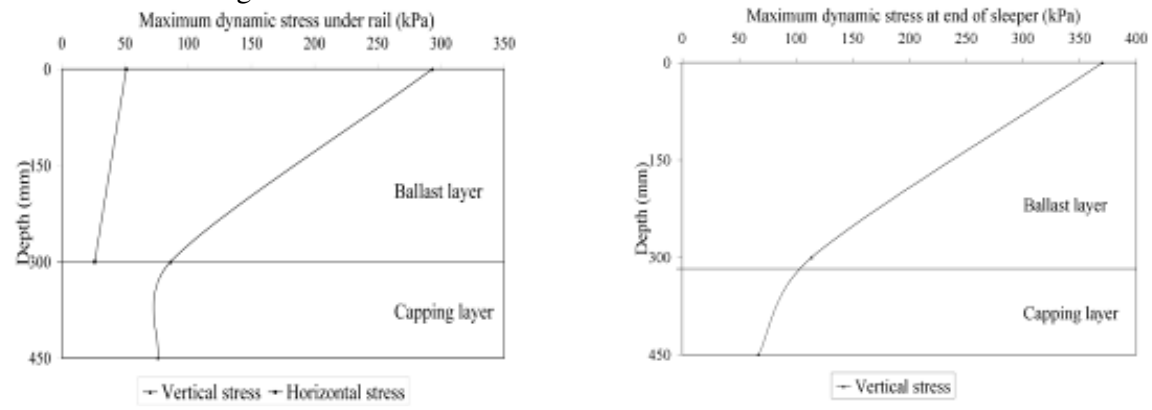

Figure 8: Maximum dynamic pressure measured (a) under rail (b) at end of sleepers for 100T coal wagon.

\section{Test Results and Analysis}

Figure 10 shows the excess pore pressures ratio $\left(u^{*}\right)$ versus the number of loading cycles $(N)$ under the partially drained condition with PVD. Excess pore ware pressure ratio $\left(u^{*}\right)$ is defined as the excess pore water pressure normalised to the initial effective pressure (Miller et al. 2000; Zhou and Gong 2001). The response of the six transducers shows the effect of the drainage path length on the development of the excess water pore pressures. Measured excess pore pressures and the corresponding excess pore water pressure ratio $\left(u^{*}\right)$ versus the number of loading cycles $(N)$ under the 
three separate series of tests are shown in Figure 11(a). Without PVD, the excess pore pressure increased rapidly $\left(u^{*} \approx 0.9\right)$, and undrained failure occurred very quickly. In contrast, with PVD, the excess pore pressure increased to a constant value $\left(u^{*}<0.4\right)$ after 500 loading cycles. As expected, the excess pore pressures measured at T3 and T4 were the lowest (i.e. shortest drainage path), while the highest values were observed at T1 and T6 (Figure 10). The data confirm the effectiveness of PVD in reducing the rapidly induced excess pore water pressures under cyclic loads, thereby mitigating potential undrained failure. Figure 11(b) presents the development of volumetric strains (compression) with the number of cycles associated with the dissipation of the excess pore pressures with PVD. As expected, the volumetric strains approach a constant level at $1.7 \%$ in compliance with the relatively constant $u^{*}$. For the tests without PVD, the measured volumetric strains were almost zero (Figure 11b) as the cyclic load applications were carried out under totally undrained conditions.

During the application of cyclic loads, the PVD significantly decreases the build up of excess pore water pressure, and also accelerates its dissipation during any rest period. In reality, the dissipation of the pore water pressure during the rest period will make the track more stable for the next loading stage (i.e. subsequent passage of train). Soft formation beneath rail track stabilised by radial drainage (PVD) can be subjected to cyclic stress levels higher than the critical cyclic stress ratio without causing undrained failure.

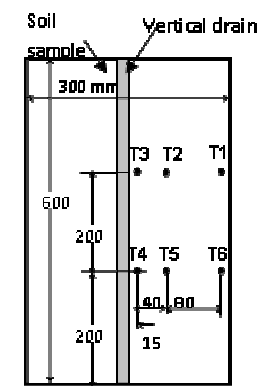

Figure 9: Locations of the pore pressure transducers at different positions from the PVD inside the soil sample (Indraratna et al., 2009).

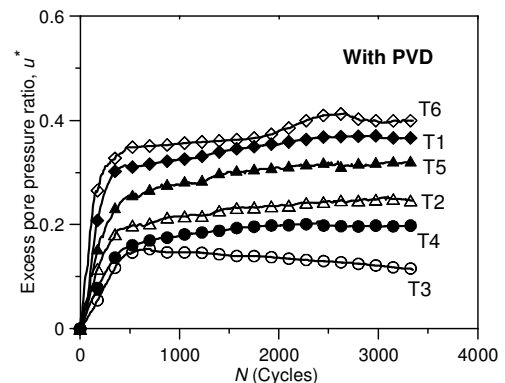

Figure 10: Excess pore pressures generated inside the soil sample at different locations from the

PVD with the application of cyclic loads (Indraratna et al., 2009).

\section{Design Process for Short PVDs under Railway Track}

The Sandgate Rail Grade Separation Project is located at the town of Sandgate between Maitland and Newcastle, in the Lower Hunter Valley of NSW (Fig. 12). The new railway tracks were required to reduce the traffic in the Hunter Valley Coal network. In this section, the rail track stabilised using short PVDs in the soft subgrade soil is presented together with the background of the project, the soil improvement details, design methodology and finite element analysis. The effectiveness of PVDs in improving soil condition has been demonstrated by Indraratna et al. (2010). Preliminary site investigations were conducted for mapping the soil profile along the track. In-situ and laboratory testing programs were carried out to provide relevant soil parameters. Site investigation included 6 boreholes, 14 piezocone (CPTU) tests, 2 in-situ vane shear tests and 2 test pits. Laboratory testing such as soil index property testing, standard oedometer testing and vane shear testing were also performed.

A typical soil profile showed that the existing soft compressible soil thickness varies from $4 \mathrm{~m}$ to $30 \mathrm{~m}$. The soft residual clay lies beneath the soft soil layer followed by shale bedrock. The soil properties are shown in Fig. 13. The groundwater level is at the ground surface. The moisture contents of the soil layers are the same as their liquid limits. The soil unit weight varies from 14 to $16 \mathrm{kN} / \mathrm{m}^{3}$. The undrained shear strength increases from about 10 to $40 \mathrm{kPa}$. The clay deposit at this site can be considered as lightly overconsolidated (OCR $\approx 1-1.2)$. The horizontal coefficient of consolidation $\left(c_{h}\right)$ is $\sim 2-10$ times the vertical coefficient of consolidation $\left(c_{v}\right)$. Based on preliminary numerical analysis conducted by Indraratna et al. (2010), PVDs having $8 \mathrm{~m}$ length were suggested and installed at $2 \mathrm{~m}$ 
spacing in a triangular pattern. Extensive field instrumentation including settlement plates, inclinometers and vibrating wire piezometers were employed to monitor the track responses. The settlement plates were installed above the surface of the subgrade layer to directly provide a measurement of the vertical subgrade settlement. The main aims of the field monitoring were to:

(a) ensure the stability of track;

(b) validate the design of the track stabilised by PVDs; and

(c) examine the accuracy and reliability of the numerical model through Class A predictions (the field measurements were unavailable at the time of finite element modelling).

\section{Preliminary Design}

Due to the time constraint, the rail track was built immediately after installing PVDs. The train load moving at very low speed $(60 \mathrm{~km} / \mathrm{h})$ was used as the only external surcharge. The equivalent dynamic loading using an impact load factor was used to predict the track behaviour. In this analysis, a static pressure of $104 \mathrm{kPa}$ with an impact factor of 1.3 was applied according to the low train speed for axle loads up to 25 tonnes, based on the Australian Standards AS 1085.14-1997. The Soft Soil model and Mohr-Coulomb model were both employed in the finite element code, PLAXIS. The overcompacted surface crust and fill layer were simulated by the Mohr-Coulomb theory, whereas the soft clay deposit was conveniently modelled using the Soft Soil model. The formation was separated into 3 distinct layers, namely ballast and fill, Soft soil-1 and Soft soil-2. The soil parameters are given in Table 2.

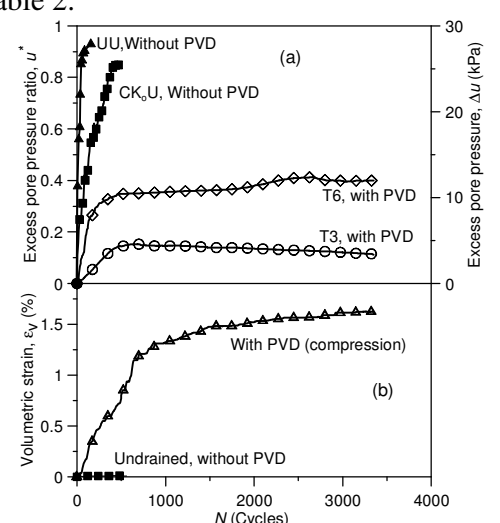

Figure 11: (a) Excess pore pressures generated with and without PVD under cyclic loads, (b)

Volumetric compressive strains developed under cyclic loads with PVD (Indraratna et al., 2009).

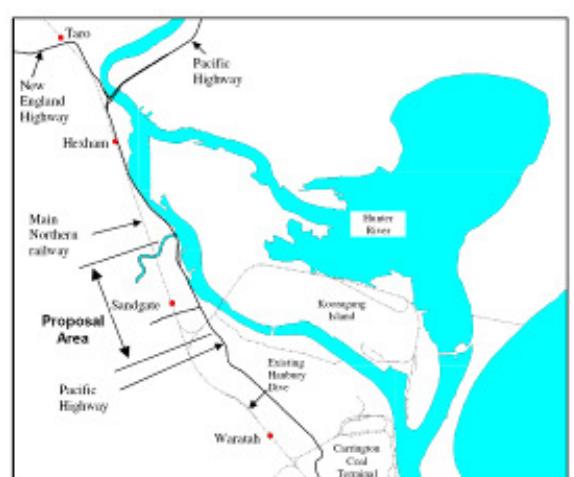

Figure 12: Site location (adopted from Indraratna et al., 2010).

A cross-section of the finite element mesh discritization of the formation beneath the track is shown in Fig. 14. A plane strain finite element analysis has been employed with linear strain triangular elements with 6 displacement nodes and 3 pore pressure nodes. A total of 4 PVD rows were used in the analysis. An equivalent plane strain analysis with appropriate conversion from axisymmetric to 2D was adopted to analyse the multi-drain problem (Indraratna et al., 2010). In this method, the corresponding ratio of the smear zone permeability to the undisturbed zone permeability is given by:

$$
\begin{gathered}
\frac{k_{s, p s}}{k_{h, p s}}=\frac{\beta}{k_{h, p s} / k_{h, a x}\left[\ln (n / s)+k_{h, a x} / k_{s, a x} \ln (s)-0.75\right]-\alpha} \\
\alpha=0.67(n-s)^{3} / n^{2}(n-1), \\
\beta=2(s-1)\left[n(n-s-1)+0.33\left(s^{2}+s+1\right)\right] / n^{2}(n-1)
\end{gathered}
$$




$$
\begin{aligned}
& n=d_{e} / d_{w} \\
& s=d_{s} / d_{w}
\end{aligned}
$$

In the above expressions, $d_{\varepsilon}=$ the diameter of unit cell soil cylinder, $d_{s}=$ the diameter of the smear zone, $d_{w}=$ the equivalent diameter of the drain, $k_{s}=$ horizontal soil permeability in the smear zone, $k_{h}=$ horizontal soil permeability in the undisturbed zone and the top of the drain and subscripts ' $a x$ ' and ' $p s$ ' denote the axisymmetric and plane strain condition, respectively.

The ratio of equivalent plane strain to axisymmetric permeability in the undisturbed zone can be attained as,

$$
k_{h, p s} / k_{h, a x}=0.67(n-1)^{2} /\left[n^{2}[\ln (n)-0.75]\right]
$$

In the above equation, the equivalent permeability in the smear and undisturbed zone varies with the drain spacing.

Table 2: Selected parameters for soft soil layer used in the FEM (Indraratna et al. 2010).

\begin{tabular}{llllllll}
\hline Soil layer & $\begin{array}{l}\text { Depth of } \\
\text { layer }(\mathrm{m})\end{array}$ & $\mathrm{c}(\mathrm{kPa})$ & $\phi$ & $e_{0}$ & $\lambda$ & $\kappa$ & $k_{h}\left(\times 10^{-4}\right.$ \\
& & & $/\left(1+e_{0}\right)$ & $/\left(1+e_{0}\right)$ & $\mathrm{m} /$ day $)$ \\
Soft soil-1 & $1.0-10.0$ & 10 & 25 & 2.26 & 0.131 & 0.020 & 1.4 \\
Soft soil-2 & $10.0-20.0$ & 15 & 20 & 2.04 & 0.141 & 0.017 & 1.5 \\
\hline
\end{tabular}

Note: $\phi$ Back-calculated from Cam-clay $M$ value.

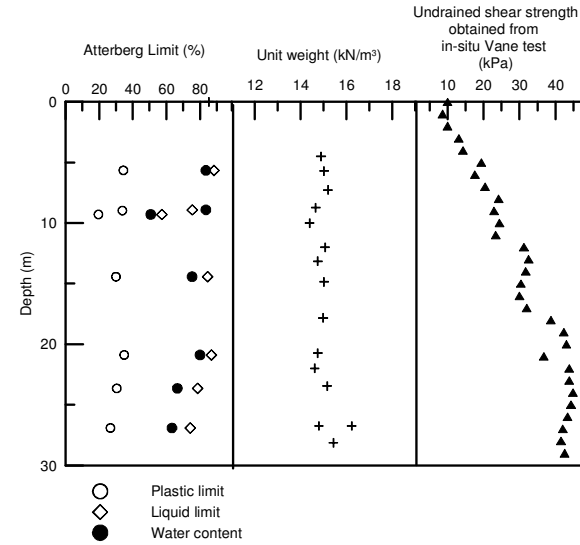

Figure 13: Soil properties at Sandgate Rail Grade Separation Project (Indraratna et al., 2010).

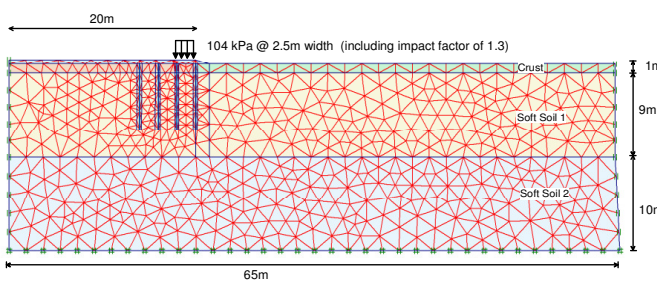

Figure 14: Vertical cross section of rail track and foundation (Indraratna et al,. 2010). 


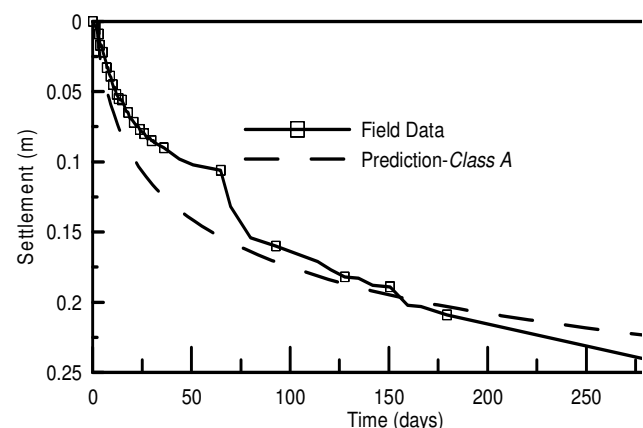

Figure 15: Predicted and measured at the centre line of rail tracks (after Indraratna et al., 2010).

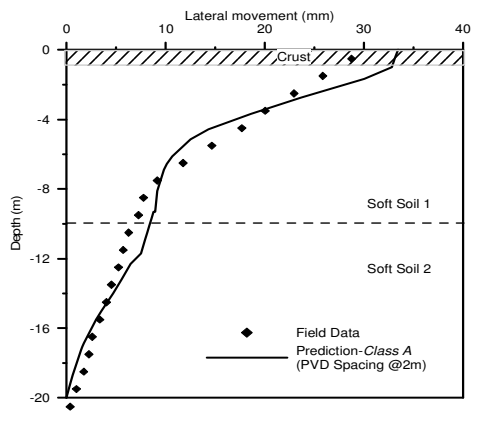

Figure 16: Measured and predicted lateral displacement at the embankment toe at 180 days (after Indraratna et al., 2010).

\section{Comparison of field with numerical predictions}

The field results were released by the track owner (Australian Rail Track Corporation) one year after the finite element predictions. Therefore all predictions can be categorized as Class A. A spacing of $2 \mathrm{~m}$ was adopted for Mebra (MD88) vertical drains of $8 \mathrm{~m}$ in length. The field data together with the numerical predictions are compared and discussed. The calculated and observed consolidation settlements at the centre line are now presented in Fig. 15. The predicted settlement matches very well with the field data. The in-situ lateral displacement at 180 days at the rail embankment toe is illustrated in Fig. 16. As expected, the maximum displacements are measured within the top clay layer, i.e., the softest soil below the $1 \mathrm{~m}$ crust. The lateral displacement is restricted to the topmost compacted fill (0-1m deep). The Class A prediction of lateral displacements is also in very good agreement with the field behaviour.

\section{SOIL STABILIZATION USING LIGNOSULFONATE}

Lignosulfonates were commonly used to stabilise cohesive to non-cohesive soils. These stabilisers are made from waste liquor by-products from wood processing industries such as paper mills (Karol, 2003). For stabilization purposes, solutions of lignosulfonate were used as raw liquor or used with other additives to achieve desire soil properties. In the recent past, investigations were carried out on cohesive soils with lignosulfonate as stabilisers on the strength improvement of cohesive soils (Puppala and Hanchanloet, 1999; Pengelly et al. 1997; Tingle and Santori, 2003). It has been reported that lignosulfonate with sulphuric acid as additive showed a profound increase in their shear strength and resilient modulus. Tingle and Santori (2003) investigated the effect of lignosulfonate on different clayey soils and found that lignosulfonate stabiliser significantly improved the strength of a low plasticity clayey soil. Again, a solution containing ammonium lignosulfonate and potassium chloride was injected into expansive soil and a significant reduction in the swelling was observed (Pengelly et al. 1997). In addition, a number of researchers have performed experiments to investigate whether this particular type of chemical would improve the strength of sub-grade and control dust emission in low volume road construction (e.g. Chemstab 2003; Tingle and Santori 2003; Lohnes and Coree 2002).

Studies have been carried out by several researchers in the recent past to understand the erosion mechanism and its dependability on different factors such as soil properties, and the properties of pore and eroding fluids. Sherard et al. (1976) developed the standard pinhole test to study the erosion characteristics of soil by pushing eroding fluid through a 1-mm crack. Wan and Fell (2004) performed erosion tests by applying a hydraulic gradient across a $6 \mathrm{~mm}$ internal crack to study the erosion characteristics of unsaturated soil in cracks of embankment dams. In this presented study, internal crack erosion behaviour of chemically treated soil has been investigated using Process Simulation Apparatus for Internal Crack Erosion (PSAICE). All the tests were carried out by pushing the eroding fluid through a $10 \mathrm{~mm}$ soil crack formed at the centre of the sample. 


\section{Materials and Methods}

The erodible soil (e.g. silty sand) used in internal crack erosion tests was collected from Wombeyan caves, New South Wales (NSW), Australia. The soil contains about 50\% sand, $44 \%$ silt, and 6\% clay. According to the standard pinhole test (ASTM D 4647), the erodible soil can be classified as D1 type dispersive soil. The maximum dry density and optimum moisture content for erodible soil were observed to be $1711 \mathrm{~kg} / \mathrm{m}^{3}$ and $10.3 \%$, respectively

For this study, general purpose Portland cement and lignosulfonate were selected as admixtures. The lignosulfonate is a completely soluble, dark brown liquid having a $\mathrm{pH}$ value of approximately 4 . It is characterised as inflammable, non-corrosive and non-hazardous chemical according to the National Occupational Health and Safety Commission (NOHSC) criteria (Chemstab, 2003).

Figure 17 shows the photograph of the test apparatus (PSAICE). This equipment has an adjustable head tank capable of applying a hydraulic gradient of up to 40 across the samples. Pressures across the samples were measured using electronic transducers and an inline turbidity meter was installed downstream of the sample to continuously monitor the effluent turbidity. The effluent was continuously weighed with an electronic balance in order to measure the flow rate. Detailed explanations of the testing equipment can be found in Indraratna et al.(2008).

Various amounts of lignosulfonate $[(0.1 \%-0.6 \%)$, by dry weight of soil] were selected to stabilise the erodible soils. The soils were mixed with the predetermined amount of lignosulfonate additive and statically compacted to $95 \%$ of the dry density inside a copper mould having a size of $72 \mathrm{~mm}$ diameter and $100 \mathrm{~mm}$ height. The prepared samples were wrapped in moisture proof bag and cured for seven days. After curing, these samples were immersed in the eroding fluid (tap water) until saturation. Internal crack erosion tests were then carried out by pushing the eroding fluid through a 10 -mm soil crack formed at the centre of the samples using the PSAICE.

\section{THEORETICAL CONSIDERATION}

Internal erosion behaviour of lignosulfonate treated and untreated soils were studied using PSAICE. Predicted erosion rate and hydraulic shear stress were used to calculate the erosion parameters, namely, the critical shear stress and the coefficient of soil erosion. The critical shear stress, $\tau_{c}$, is defined as the minimum hydraulic shear stress necessary to initiate erosion. Figure 18 shows the variation of the erosion rate with the hydraulic shear stress. The critical shear stress is estimated by extrapolating the straight line to the zero erosion rate. The slope of the linear line was presumed to be the coefficient of soil erosion. During the test, the flow rate was observed to be increasing with time. The amount of soil eroded in a particular time interval $\delta t$ can be represented as:

$$
\delta m=k Q T \times \delta t
$$

where, $\delta m(\mathrm{~kg})$ is the amount of dry soil eroded during a selected time interval $\delta t, Q\left(\mathrm{~m}^{3} / \mathrm{s}\right)$ is the average flow rate through the soil crack at time interval $\delta t ; T$ (NTU) is the average turbidity of the effluent at $\delta t$; and $k\left(\mathrm{~kg} / \mathrm{m}^{3} / \mathrm{NTU}\right)$ is the empirical factor relating turbidity to the soil solids concentrated in the flow.

The value of $k$ was evaluated from the linear relationship between soil concentration and turbidity, as shown in Figure 18. The value was estimated to be $0.011 \mathrm{~kg} / \mathrm{m}^{3} / \mathrm{NTU}$ for lignosulfonate treated silty sand and $0.002-0.011 \mathrm{~kg} / \mathrm{m}^{3} / \mathrm{NTU}$ was observed for treated and untreated dispersive clay. In addition, when the diameter of the soil crack changes by $\delta \phi_{t}$ in a time interval $\delta t$, the amount of soil eroded during this time will be:

$$
\delta m=\frac{\pi \phi_{t} l \rho_{d}}{2} \times \delta \phi_{t}
$$

Where, $\rho_{d}\left(\mathrm{~kg} / \mathrm{m}^{3}\right)$ is the dry density of compacted soil; $l(\mathrm{~m})$ is the length of the soil crack; and $\phi_{t}(\mathrm{~m})$ is the diameter of the soil crack at time $t$. 


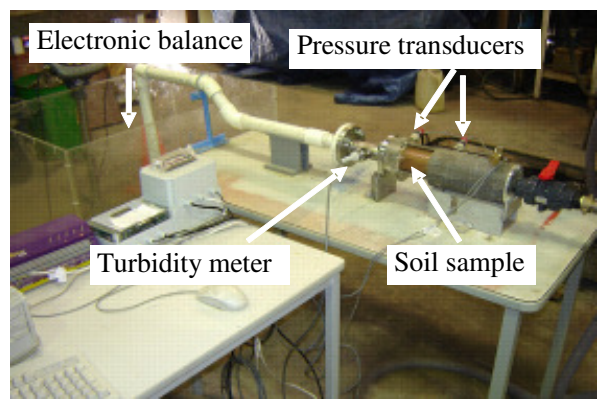

Figure 17: Photograph of Process Simulation Apparatus for Internal Crack Erosion (PSAICE) (Indraratna et al., 2008).

Equating expressions (3) \& (4)

$$
\delta \phi_{t}=\frac{2 k Q T}{\pi \phi_{t} l \rho_{d}} \times \delta t
$$

The erosion rate, $\dot{\varepsilon}\left(\mathrm{kg} / \mathrm{s} / \mathrm{m}^{2}\right)$, can then be calculated using Equation (5).

$$
\dot{\varepsilon}=\frac{k Q T}{\pi \phi_{t} l}
$$

\section{Estimation of Hydraulic Shear Stress from Friction Factor Method}

The hydraulic shear stress is estimated from:

$$
\tau_{a}=\frac{f \rho_{w} v^{2}}{8}
$$

where, $f$ is the friction factor, $\rho_{w}\left(\mathrm{~kg} / \mathrm{m}^{3}\right)$ is the density of the eroding fluid; and $v(\mathrm{~m} / \mathrm{s})$ is the mean velocity of the flow through the crack at time $t$, which can be calculated using the flow rate and diameter of the crack. The friction factor was calculated from the Moody diagram (Abulnaga, 2002) based on the relative roughness and Reynolds number. The relative roughness is calculated from

$$
\varepsilon=\frac{D}{2 \phi_{i}}
$$

where, $D(\mathrm{~m})$ is the mean particle diameter. The height of the roughness element was taken as the radius of the mean particle. The mean particle diameter was estimated from particle size distribution of the eroded particles obtained from the Malvern Mastersizer.

The Reynolds number can be calculated using Equation (8):

$$
R_{e}=\frac{\rho_{w} v \phi_{i}}{\mu}
$$

where, $\mu\left(\mathrm{kgm}^{-1} \mathrm{~s}^{-1}\right)$ is the dynamic viscosity of the eroding fluid

\section{Results and Discussions}

Figure 19 presents the variation of erosion rate with hydraulic shear stress for lignosulfonate treated and untreated silty sand at $95 \%$ of the maximum dry density. It is evident from Figure 19 that the erosion rate and hydraulic shear stress follow a linear relationship and the slope represents the coefficient of soil erosion. As expected, critical shear stress increases and coefficient of soil erosion decreases with the increase in the amount of lignosulfonate. When the amount of lignosulfonate is increased to $0.6 \%$, the critical shear stress increases from $0.8 \mathrm{~Pa}$ to $65 \mathrm{~Pa}$. In addition, the coefficient of soil erosion decreases from $0.265 \mathrm{sm}^{-1}$ to $0.003 \mathrm{sm}^{-1}$. Lignosulfonate treated dispersive clay also exhibited a similar behaviour (critical shear stress increases and coefficient of soil erosion decreases, with the amount of lignosulfonate) as that of silty sand (Figure 19). The critical shear stress increases 
from 3.6 $\mathrm{Pa}$ to $27 \mathrm{~Pa}$ with the addition of $0.6 \%$ of lignosulfonate and coefficient of soil erosion decreases from $0.019 \mathrm{sm}^{-1}$ to $0.0012 \mathrm{sm}^{-1}$.

\section{Comparison with Traditional Admixtures}

The behaviour of lignosulfonate treated soils (silty sand and dispersive clay) has been compared with cement treated soils. General purpose Portland cement was used for soil stabilisation and erosion tests were carried out on cement treated soils very similar to lignosulfonate stabilised soils. Figure 19 present the variation of erosion rate versus hydraulic shear stress for silty sand, respectively. It can be observed from Figures 20 that critical shear stress increases and the coefficient of soil erosion decrease with the increase in cement. This behaviour is very similar to that reported for lignosulfonate treated soils (Fig. 19).

The improvement of performance in terms of critical shear stress due to addition of chemical additives (lignosulfonate and cement) can be represented as a non-dimensional Critical Shear Stress Ratio (CSSR), which is defined as the ratio of critical shear stress of treated soil to the critical shear stress of untreated soil.

The variation of critical shear stress ratio for lignosulfonate and cement treated soils (silty sand) is tabulated in Table 3. It is evident from Table 3 that for silty sand CSSR of 7.5 was achieved with 0.1 $\%$ of lignosulfonate. In contrast, for cement treated silty sand the same value of CSSR (7.5) was observed at $0.5 \%$ of cement content. For silty sand the performance improvement in terms of CSSR was observed to be higher for a less amount of lignosulfonate when compared to cement. However, for silty clay, the performance improvement in terms of CSSR was observed to be slightly higher for cement treated soil when compared to lignosulfonate. Studies are in progress to understand the stabilization mechanism involved in the lignosulfonate treated dispersive clay.

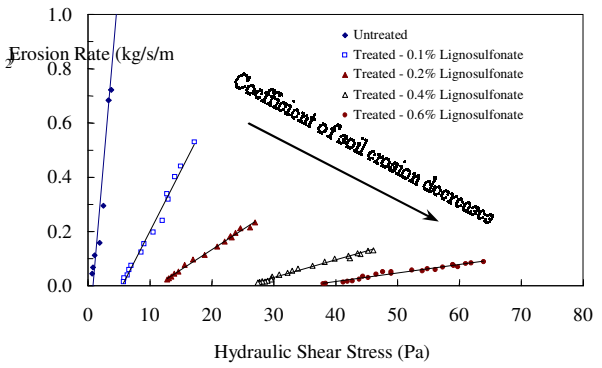

Figure 19: Erosion rate against hydraulic shear stress for lignosulfonate treated and untreated silty sand (Indraratna et al., 2009).

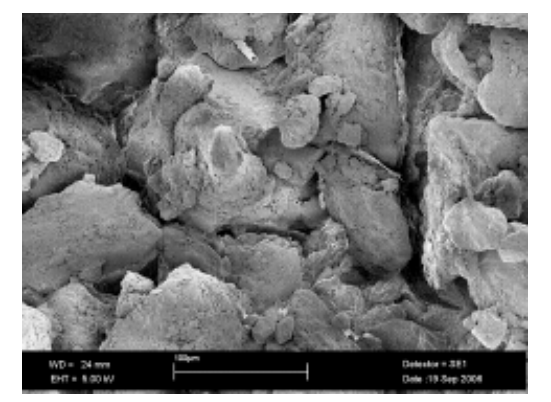

Figure 21: SEM photograph-untreated silty sand (after Indraratna et al., 2008).

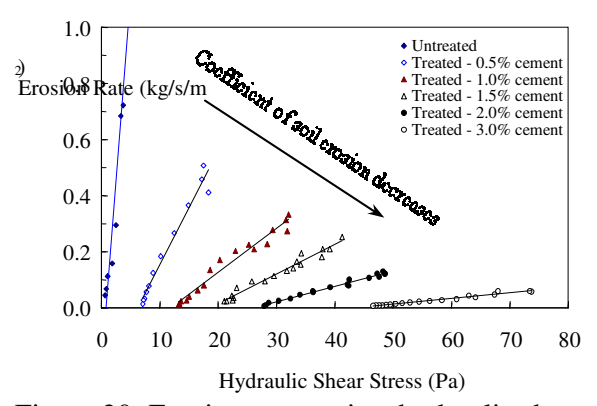

Figure 20: Erosion rate against hydraulic shear stress for cement treated and untreated silty sand (Indraratna et al., 2009).

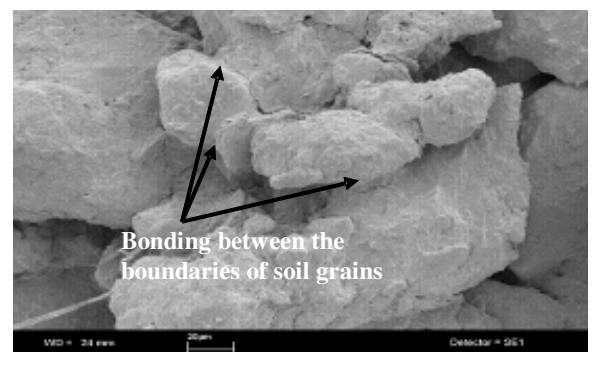

Figure 22: SEM photograph - $0.2 \%$ lignosulfonate treated silty sand (after Indraratna et al., 2008). 
Table 3: Variation of critical shear stress ratio for different lignosulfonate and cement treated soils.

\begin{tabular}{|c|c|c|c|}
\hline \multirow{2}{*}{ Soil Type } & $\begin{array}{c}\text { Amount of } \\
\text { chemical }(\%)\end{array}$ & \multicolumn{2}{|c|}{ Critical Shear Stress Ratio (CSSR) } \\
\cline { 2 - 4 } & Lignosulfonate & Cement \\
\hline \multirow{3}{*}{ Silty sand } & 0.1 & 7.5 & - \\
\cline { 2 - 4 } & 0.2 & 13.8 & - \\
\cline { 2 - 4 } & 0.4 & 31.3 & - \\
\cline { 2 - 4 } & 0.5 & - & - \\
\cline { 2 - 4 } & 0.6 & 43.8 & 16.3 \\
\cline { 2 - 4 } & 1.0 & - & 31.3 \\
\cline { 2 - 4 } & 1.5 & - & 53.8 \\
\hline
\end{tabular}

Digital images using Scanning Electron Microscope (SEM) were used to understand the stabilization mechanism of lignosulfonate treated silty sand. As seen in Figure. 21, untreated soil grains are distinctly separate with clear boundaries between them. However, with lignosulfonate addition (Figure. 22), the particles become coated with this chemical, which bonds them closely together to produce a stronger soil structure. Based on these observations from the SEM analysis, it may be concluded that the lignosulfonate stabiliser act like cementing agents to bind the particles together to form an erosion resistant surface.

\section{Stabilization Mechanism of Lignosulfonate treated dispersive soil}

A schematic diagram (Figure. 23) explaining the mechanism of lignosulfonate treated soil has been developed based on the FTIR and XRD analysis. The detailed hydrolysis reaction based on FTIR and XRD analysis can be found in Vinod et al. (2010). Figure. 23(a) shows the untreated soil particles with negative charges in the interstitial layer of clay minerals. Once the lignosulfonate is mixed with water, it participates in hydrolysis reaction resulting in positively charged compounds.

When the lignouslfonate-water mixture is mixed with the soil (Figure. 23(b)), the positively charged lignosulfonate is adsorbed on the surface of clay minerals and forms bonding by electrostratic attraction. Positively charged lignosulfonate is attracted by negative charged clay mineral, resulting in the reduction of interstial double layer water (Figure. 23(c)). Then the lignosulfonate polymer chain binds the soil particles together and forms soil aggregates (Figure. 23(d)). The formation of soil aggregates by lignosulfonate treatment has been confirmed using SEM images of treated erodible soil as presented by Indraratna et al. (2008).

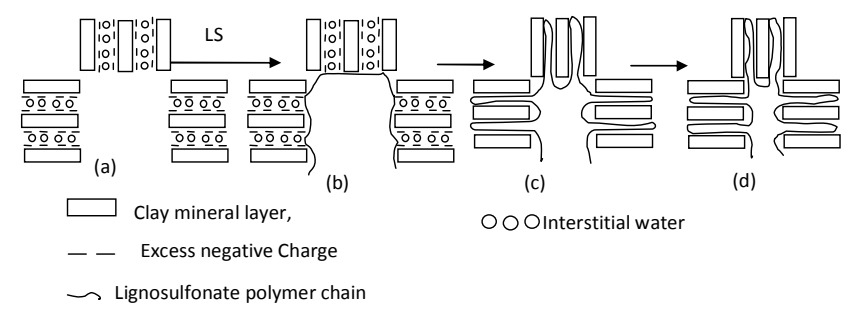

Figure 23: Schematic diagram of stabilization mechanism for lignosulfonate treated soil (Vinod et al., 2010).

\section{CONCLUSIONS}

Several physical and chemical ground improvement techniques have been discussed in this paper, including geosynthetic reinforcement, PVDs, lignosulfonate stabilizer and cement stabilizer. The performance of ballasted rail tracks with geosynthetic reinforcement has been described through field investigations. The results highlight that particle breakage and confining pressure have a significant 
influence on the permanent deformation of ballast. The performance of instrumented ballasted track at Bulli was evaluated where different types of geosynthetic reinforcements were used. This study confirmed that various forms of geosynthetic layers minimise the deformation and degradation of fresh ballast. It was shown that fresh ballast performs satisfactorily under repeated train loads when reinforced with suitable type of geosynthetics, e.g., woven-geotextiles, geogrids and geocomposites. Settlement in fresh ballast was significantly reduced when geosynthetics were inserted. Use of geosynthetics in recycled ballasted track also proved to be a feasible and effective alternative.

Based on large scale triaixal test results, it is shown that PVDs can decrease the buildup of excess pore water pressure during cyclic loading, and also continue to dissipate excess pore water pressure during the rest period. The dissipation of the pore water pressure during the rest period makes the track more stable for the next loading stage. Even with the relative short PVDs, both the predictions and field data prove that the lateral displacement can be curtailed. The equivalent plane strain finite element analysis is adequate to predict the behaviour of track improved by short PVDs, as long as the soil parameters are known to a good accuracy from laboratory and field testing. From the ratio of maximum horizontal displacement to vertical displacement and measured excess pore pressure, the effectiveness of wick drains in reducing the effects of undrained cyclic loading can be demonstrated here.

For non-toxic chemical stabilization, the experimental study was conducted to evaluate the critical shear stress and the coefficient of soil erosion stabilised by lignosulfonate. Results of the presented study showed that the potentiality of lignosulfonate to stabilise the erodible soils against internal crack erosion. It was found that the lignosulfonate stabilizer would reduce the coefficient of soil erosion and significantly increased the critical shear stress for both clayey and silty soils. The improvement of performance of critical shear stress was expressed in terms of critical shear stress ratio (CSSR). The increase in the critical shear stress of the silty sand with only $0.6 \%$ lignosulfonate treatment was equivalent to that with around $2.5 \%$ cement treatment. Moreover, micro-chemical analysis revealed that the improvement of performance exhibited by the lignosulfonate treated soil is attributed to the reduction of the double layer thickness by the neutralization of surface charges of the clay particles and the subsequent formation of a stable particle cluster or aggregate.

\section{ACKNOWLEDGEMENTS}

The authors express their sincere gratitude to Cooperative Research Center for Rail Innovation (Rail-CRC), RailCorp of NSW and related geosynthetics companies in Australia for their support and cooperation. Support provided by the Australian Research Council is greatly acknowledged. Much of the contents reported in this paper are described in detail in a number of scholarly journals includes Geotechnique, Canadian Geotechnical Journal and ASCE Journal of Geotechnical and Geoenvironmental Engineering, as cited in the text and listed below.

\section{REFERENCES}

Abulnaga, B. 2002. Slurry Systems Hand Book. McGraw- Hill, New York, 2.11.

Ansal, A. M. and Erken, A. 1989. Undrained behaviour of clay under cyclic shear stresses. Journal of Geotechnical Engineering, ASCE, 115(7), pp. 968-983.

ASTM. 2002. Standard test method for undrained triaxial compression test for cohesive soils. ASTM D4767-02.

Balasubramaniam, A.S., Bergado, D.T., Buensuceso, B.R. and Yang, W.C. 1998. Strength and deformation characteristics of lime-treated soft clays. Geotechnical Engineering, 20(1): 49- 65.

Chang, C. S. 1982. Residual undrained deformation from cyclic loading. Journal of Geotechnical Engineering Division, ASCE, 108(GT4), pp. 637-646.

Chemstab. 2003. Technical Manual, Chemstab Consulting Pty Ltd, Horsley, NSW Australia.

Chen, R., Drnevich, V.P. and Daita, R.K. 2009. Short-term electrical conductivity and strength development of lime kiln dust modified soils. Journal of Geotechnical and Geoenvironmental Engineering, 135(4): 590-594. 
Chew, S.H., Kamruzzaman, A.H.M. and Lee, F.H. 2004. Physicochemical and engineering behavior of cement treated clays. Journal of Geotechnical and Geoenvironmental Engineering, 130(7): 696706.

Desmet, J., Gabriels, D. and Dierickx, W. 1985 Effect of soil conditioners on the permeability and stability of soils, J. Sci. Food Agric., 36, 242-248.

Indraratna, B., Balasubramaniam, A. and Balachandran, S. 1992. Performance of test embankment constructed to failure on soft marine clay. Journal of Geotechnical Engineering, ASCE, 118(1), pp.12-33.

Indraratna, B., Balasubramaniam, A.S. and Khan, M.J. 1995. Effect of fly ash with lime and cement on the behaviour of a soft clay, Quarterly Journal of Engineering Geology \& Hydrogeology, 28(2): 131-142.

Indraratna, B., Muttuvel, T. and Khabbaz H. 2009. Modelling the erosion rate of chemically stabilized soil incorporating tensile force-deformation characteristics. Canadian Geotechnical Journal, 46: 5768.

Indraratna, B., Muttuvel, T., Khabbaz, H. and Armstrong, B. 2008. Predicting the erosion rate of chemically treated soil using a process simulation apparatus for internal crack erosion. J. of Geot. and Geo-envi. Engg, ASCE, 134(6): 837-844.

Indraratna, B., Attya, A. and Rujikiatkamjorn, C. 2009. Experimental Investigation on effectiveness of a vertical drain under cyclic loads. Journal of Geotechnical and Geoenvironmental Engineering, ASCE, 135(6), pp. 835-839.

Indraratna B., Ionescu D. and Christie, D. 1998. Shear behaviour of railway ballast based on largescale triaxial tests, Journal of Geotechnical and Geoenvironmental Engineering, ASCE, 124(5): 439-439.

Indraratna B., Khabbaz, H., Salim, W. and Christie, D. 2003. Geotechnical characteristics of railway ballast and the role of geosynthetics in minimising ballast degradation and track deformation. In: RAILTECH 2003 - Railway Technology in the New Millennium; 2003; Kuala Lumpur, Malaysia: 3.1-3.22.

Indraratna, B., Lackenby, J. and Christie, D. 2005. Effect of confining pressure on the degradation of ballast under cyclic loading. Geotechnique, Institution of Civil Engineers, UK, 55(4): 325-328.

Indraratna, B. and Salim, W. 2002. Modeling of particle breakage of coarse aggregates incorporating strength and dilatancy. Geotechnical Engineering, Proceedings of the Institution of Civil Engineers, London, 155(4): 243-252.

Indraratna, B. and Salim, W. 2005. Mechanics of ballasted rail tracks - A geotechnical perspective, A. A. Balkema - Taylor and Francis, UK.

Indraratna, B., Nimbalkar, S., Christie, D., Rujikiatkamjorn, C. and Vinod J.S. 2010. Field Assessment of the Performance of a Ballasted Rail Track with and without Geosynthetics, J. of Geotech. and Geoenviron. Engng ASCE, 136(7), 907-917.

Indraratna, B. and Salim, W. 2003 Deformation and degradation mechanics of recycled ballaststabilised with geosynthetics Soils and Foundations 43(4) 35-46

Indraratna, B. and Salim, W. 2005. Mechanics of ballasted rail tracks - A geotechnical perspective, A. A. Balkema - Taylor and Francis, UK.

Indraratna, B., Shahin, M.A, and Salim, W. 2007. Stabilising Granular Media and Formation Soil using Geosynthetics with Special Reference to Railway Engineering, J. of Ground Improvement, 11(1) 27-44.

Indraratna, B., Khabbaz, H., Salim, W., Lackenby, J. and Christie, D. 2004. Ballast characteristics and the effects of geosynthetics on rail track deformation. In: International Conference on Geosynthetics and Geoenvironmental Engineering, ICGGE; 2004; Bombay, India: 3-12.

Indraratna, B., Rujikiatkamjorn, C., Ewers, B. and Adams, M. 2010. Class A prediction of the behaviour of soft estuarine soil foundation stabilised by short vertical drains beneath a rail track. Journal of Geotechnical and Geoenvironmental Engineering. Vol. 136. No. 5, pp. 686-696.

Ionescu D, 2004. Evaluation of the engineering behaviour of railway ballast $\mathrm{PhD}$ thesis, School of Civil, Mining and Environmental Engineering, University of Wollongong, Wollongong.

Lackenby, J., Indraratna, B. and McDowel, G. 2007. The Role of Confining Pressure on Cyclic Triaxial Behaviour of Ballast. Geotechnique, Institution of Civil Engineers, UK 57(6): 527-536. 
Lohnes, R.A. and Coree, B.J. 2002. Determination and evaluation of alternative methods for managing and controlling highway-related dust. Final Report TR 449, Iowa Highway Research Board.

Marsal, R.J. 1973. Embankment dam engineering - mechanical properties of rockfill, Wiley Pub., New York, 109-200.

Miller, G.A., Teh, S.Y., Li, D. and Zaman, M.M. 2000. Cyclic shear strength of soft railroad subgrade. Journal of Geotechnical and Geoenvironmental Engineering, ASCE, 126(2), 139-147.

Pengelly, A.D., Boehm, D.W., Rector, E. and Welsh, J.P. 1997. Engineering experience with in-situ modification of collapsible and expansive soils. Unsaturated soil engineering practice, ASCE GSP no: 68:277-298.

Puppala, A.J. and Hanchanloet, S. 1999. Evaluation of a new chemical (SA-44/LS-40) treatment method on strength and resilient properties of a cohesive soil. Paper presented at Transportation Research Board Annual Meeting, Transportation Research Board, Washington, D.C: 1-11.

Rajasekaran, G., Murali, K. and Srinivasaraghavan, R. 1997. Fabric and mineralogical studies on lime treated marine clays. Ocean Engineering Journal, 24(3): 227-234.

Rajasekaranand, G. and Narasimha Rao, S. 1997. The microstructure of lime-stabilized marine clay, Ocean Engineering, 24(9), 867-878.

Raymond, G. P. 2002. Reinforced ballast behaviour subjected to repeated load. J. of Geot. and Geomem., 20(1):39-61.

Rowe, P.K. and Jones, C.J.F.P. 2000. Geosynthetics: innovative materials and rational design. In: Proceedings, GEOENG 2000; Melbourne, Australia: 1124-1156.

Salim, W. and Indraratna, B. 2004. A New elasto-plastic constitutive model for granular aggregates incorporating particle breakage. Canadian Geotechnical Journal, 41(4): 657-671.

Selig, E.T. and Waters, J. M. 1994. Track Geotechnology and Substructure Management, Thomas Telford, London. 2007.

Sariosseiri, F. and Muhunthan, B. 2009. Effect of cement treatment on geotechnical properties of someWashington State soils. Engineering Geology, 104(1-2): 119-125.

Sherard, J.L., Dunnigan, L.P., Decker, R.S. and Steele, E.F. 1976. Pinhole test for identifying dispersive soils. Journal of the Geotechnical Engineering Division, ASCE, 102(GT1): 69-85.

Tingle, J.S. and Santori, R.L. 2003. Stabilisation of Clay Soils with Non Traditional Additives. National Research Council, Washington, DC, Transporation Research record No.1819:72-84.

T. S. 3402: Specification for Supply of Aggregates for Ballast. Rail Infrastructure Corporation of NSW, Sydney, Aus, 2001.

Uddin, K., Balasubramaniam, A.S. and Bergado, D.T. 1997. Engineering behaviour of cement treated Bangkok soft clay. Geotechnical Engineering Journal, 28(1): 89-119.

Vinod, J.S. Indraratna, B. and Mahamud, M.A.A. 2010. Stabilisation of an erodible soil using a chemical admixture. Proceedings of the Institution of Civil Engineers Ground Improvement, 163(GII): 43-51.

Wan, C.F. and Fell, R. 2004. Investigation of erosion rate of soils in embankment dams. Journal of Geotechnical and Geoenvironmental Engineering, 130(4): 373-380.

Zhou, J. and Gong, X. 2001. Strain degradation of saturated clay under cyclic loading. Can. Geot. J., 38, pp. 208-212. 